\title{
EDITORIAL
}

\section{Human Security in Africa}

Tanya Lyons Editor, Australasian Review of African Studies President, African Studies Association of Australasia and the Pacific School of History and International Relations, Hinders University Research Fellow, Centre for Africa Studies, University of the Free State, South Africa editor@afsaap.org.au

This $38^{\text {th }}$ volume of the Australasian Review of African Studies is published at a time when Africa has once again fallen off the map in terms of Australian foreign policy. Submissions to the Australian Foreign Policy White Paper have closed, and although we are yet to see the final report, a preliminary review of these submissions (from DFAT, 2017), which aim to inform and guide how Australia will engage with the rest of the world in the years ahead, clearly demonstrates a dearth of interest in Africa (although further research on these submissions is required). This is an unsurprising trend since 2008, the heyday of Stephen Smith's and Kevin Rudd's driving force behind Labor's re-engagement with Africa - documented most adequately by Mickler and Lyons (2013).

However, this all came to a disappointing end with Tony Abbott's Liberal-Coalition electoral victory in 2013, resulting in the demise of Ausaid, and the effective end of the Australia-Africa Awards, which saw up to 1000 African scholars studying in Australia in 2013, among other Africa policies. Thus, there was a massive change of focus away from Africa and back to our nearer 'more important' regions. As to the Liberal's Foreign Affairs Minister Julie Bishop, and her enjoyment of the spoils of Rudd's obsession - to win a 2 year seat (2013-15) on the United Nations Security Council (which justified his re-engagement with Africa, as it depended on their votes to win, in the first place) - the irony of this has been noted elsewhere (see Bourke, 2014). What is important for AFSAAP here is that 
despite the geographical topsy-turvy of Africa's place on Australia's global map, Africa remains a significant area of research for postgraduate students in Australia, and a number of academics continue to focus their research on Africa - from a variety of disciplines. The forthcoming (2017) Directory and Audit of African Studies in Australia and New Zealand will no doubt, continue to support this claim (AFSAAP, 2014). Indeed, we need to go no further than the recent $\mathrm{PhD}$ completion of our very own book's review editor at ARAS, Nikola Pijovic (2016), to realise that the history of Australia's relations with Africa, while often neglected, is always present (even if volatile) to some extent in our foreign policy dealings. The 2016 AFSAAP Annual Conference at the University of Western Australia is a further case in point. A significant proportion of presentations were from postgraduate researchers in this region (AFSAAP, 2016), and a number of excellent initiatives have emerged from this meeting, including the creation of African Narratives, which will make a significant contribution to communicating research and ideas on Africa. The forthcoming 2017 AFSAAP Conference will continue to support this emerging research, but asks the question, what is the future of African Studies in Australia and New Zealand, especially in this current climate (see the Call for Papers at the end of this issue).

The university sector continues to move the goal posts, and challenge the rationale of researchers, in particular the 'if and where' they publish. ARAS is the official publication of AFSAAP and remains independent from the corporate publishing world, but the so-called 'listed' journals that universities demand their academics only publish in, remain steadfastly connected to the corporate domain. Yet, ARAS is the logical journal for the publication of research on Africa and the African diaspora in this region. Indeed, ARAS continues to receive a high volume of article submissions, which have allowed us to expand and develop our publication outputs. We now have a team of editors working towards each issue and communicating with prospective authors. We cannot publish everything we receive, but we encourage all researchers with a focus on Africa to send their submissions to ARAS first.

This issue of ARAS focuses on the issues of human security in Africa, and begins with an examination of the devastating problems facing South Sudan. In his article "Why South Sudan's problems stem from the abuse of sovereignty: The case for co-governance," Samuel Makinda reveals that the main issue is with South Sudan's sovereign statehood, and that a system of co-governance is required to restore sovereignty, and thus create security and stability. Makinda argues that this would not be neo-colonial, but would involve the African Union and the United Nations. International 
society, claims Makinda, should have predicted and prevented these failures of the world's newest state, but ultimately the blame must be shared with South Sudan's leaders.

Terrorism is the most obvious threat to human security globally and how states respond to the terrifying actions of non-state actors such as for example, Islamic State, al Shabaab, or Boko Haram, will determine their ongoing presence or hopeful demise. On this point, understanding such groups' motivations and impacts requires further research, and as such academics and researchers will need to go into the field to explore these threatening issues. Here, Iro Aghedo explores the relevance of ethics requirements for academic research(ers) in such a field - in particular where Boko Haram is operational in North Eastern Nigeria. Aghedo is an expert on the rise of Boko Haram in Nigeria and has published widely, yet in this article "Ethics and Its Discontents: Evidence from Terrorism Research in North-Eastern Nigeria", he reflects on the role of the researcher and their ability to precariously balance the requirements of the academy, and the safety of participants and the researcher in the field. Aghedo is based at the University of Benin, and has developed here a manifesto for ethical research on the impact of terrorism in North Eastern Nigeria.

Human security also requires access to health care, and where the state can provide this, it must. Kwadwo Adusei-Asante contributes a fascinating account of Ghana's National Health Insurance Scheme (NHIS), using ethnographic research to explore the motivations behind individual's choices to join or opt out of this scheme, in his article entitled "Beyond Minimisation of Personal Healthcare Financing Risks: An Ethnographic Study of Motivations for Joining Ghana's Health Insurance Scheme in Daakye District.” Daakye District is a pseudonym for the research location in Ghana. Adusei-Asante found that self-interest and family responsibilities motivated individuals to maintain their NHIS membership, but that collectivism was favoured, thereby requiring a review of the NHIS, such that it might include a 'family package' subsidised by the government. Furthermore, the recommendations include a specific focus on ensuring women have "unhindered access to medical assistance," for all of the obvious reasons to do with their maternal health and responsibility for dependents.

Access to education is another element of human security, because it provides individuals with the keys to their own future. Lois Kidmas, Greg Ashman and Megan Short, all from the University of Tasmania, have conducted research on the experiences of Nigerian migrants to Australia, in particular focusing on the teenage children of these migrants and how they have adapted to their new local high-schools. This article compares the 
pedagogical styles of both the Nigerian and Australian system, exploring the social, academic and cultural factors of the secondary schooling content in Australia, in the state of Tasmania in particular. The quote in this article's title says it all - “'My Friends Were There for Me.' Exploring the Pedagogical Adaptations of Secondary Nigerian-Australian Students in Tasmania." Having the opportunity to feel safe, develop friendships, and experience positive individual and group learning both in the classroom and through extra-curricular activities, were identified by these researchers as the key to adaptation. Kidmas, Ashman and Short's report here should be essential reading for teachers and educators in Australia and across Africa.

Migration patterns globally reveal the erosion of human security. These pages of ARAS have previously shared much research on the settlement issues facing the African diaspora in particular in Australia and New Zealand. In this contribution Hanna Jagtenberg from the University of Adelaide, presents her research on "Afrikaner émigrés in Australia: Perception vs. Reality in Human Decision-Making”. This article was awarded the 2016 Cherry Gertzel/AFSAAP Postgraduate Prize for the best postgraduate research presented at the AFSAAP Annual Conference. Her ethnographic research, based on interviews with Afrikaner immigrants who came from South Africa to Australia after 1994, examines their reasons and motivations for leaving at the end of apartheid. Jagtenberg's research is both sensitive and revealing as to the fears and perceptions of reality experienced by this cohort. She has conducted extensive fieldwork in Australia for her $\mathrm{PhD}$, and this article provides a glimpse at her initial conclusions. One of the main focus points here is on the reactions to postapartheid South Africa's affirmative action policies, which seem to have encouraged many Afrikaners to migrate from South Africa for the sake of the survival of their offspring, despite the interesting fact that it was apparently based on 'perception' rather than actual experience of discrimination.

Finally, this issue ends with a discussion of the objects in which a child's security is focused, and yet as Russell McDougall so beautifully illustrates, is no longer simply child's play. In his analysis of the appearance of 'Teddy' Bears in Africa, McDougall takes us on a fascinating journey into the psychology and politics of the famous stuffed bear into and out of Africa. From the origins and spread of the Teddy Bear, through to the saga of the teaching and learning bear in Khartoum - not to mention the African adventures of Winnie the Pooh and Paddington Bear, and the creation of the Taurina bears in Cape Town - this article makes a valuable contribution to the globalization of human security discourse and literary studies. 


\section{References}

AFSAAP, 2014. "An Audit of African Studies in Australia 2014: A Snapshot of Courses and Topics available in Australian and New Zealand Universities, in addition to names of researchers working on issues related to Africa", http://afsaap.org.au/resources/afsaaparchives/afsaap-project-2014/

AFSAAP, 2016, “Africa: Moving the boundaries: 39 ${ }^{\text {th }}$ AFSAAP Annual Conference 5-7 December 2016”, Conference Proceedings, http://afsaap.org.au/conference/perth-2016/

Bourke, Latika, 2014. "The irony behind Julie Bishop's success at the United Nations Security Council”, The Sydney Morning Herald, 20 November, http://www.smh.com.au/federal-politics/political-opinion the-irony-behind-julie-bishops-success-at-the-united-nationssecurity-council-20141120-11qcmp.html

Department of Foreign Affairs and Trade (DFAT), 2017. Submissions to the Foreign Affairs White Paper, http://dfat.gov.au/whitepaper/ submissions/index.html

Mickler, David and Lyons, Tanya (Eds.) 2013. New Engagement: Contemporary Australian Foreign Policy Toward Africa, Melbourne: Melbourne University Press

Pijovic, Nikola, 2016. From Howard to Abbott: Volatility and change in Australia's foreign policy engagement with Africa, Unpublished PhD submitted to Australian National University. 